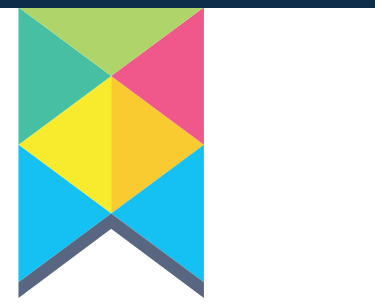

\title{
Neutral is the New Blind: \\ Calling for Gender Segregated Evidence in UK Legislative Inquiries regarding the Music Industries
}

Dr Metka Potočnik

\begin{abstract}
In late 2020, the Government responded to the enormous crisis in the UK music industries, caused by the Covid-19 pandemic, by initiating several legislative inquiries, aimed at reviewing the rules regulating the industry, including rules on commercialisation of intellectual property (IP). The aim of the Department for Digital, Culture, Media \& Sport (DCMS) inquiries is purportedly to improve the fairness and viability of the sector, which was devastated by the pandemic. At the same time, the Covid-19 crisis served as a catalyst to expose the pre-existing inequalities and unfairness in the UK music industries.

This article explores the path of the UK DCMS 2020-21 legislative inquiry into the Economics of Music Streaming as a case study to the current approach in UK regulation of the music industries. Informed by the feminist theory of relational legal feminism and embedded in the broader framework of IP Social Justice theory, the author argues that the current approach to legislative inquiries is incomplete, because it fails to take into account the systemic barriers faced by women (i.e., all who identify as women), including gender minority musicians in the sector. The evidence collected fails to investigate the lived experience of women, to the detriment of fairness of the overall proposal of future reform.
\end{abstract}

\section{Keywords}

Feminist scholarship, IP Social Justice, Intellectual Property Law, the music industries, streaming, communication to the public, Brexit, EU-derived domestic legislation, retained EU case law, evidence-led policy, legislative inquiry.

\footnotetext{
* Dr Metka Potočnik is a Senior Lecturer at the Law School of the University of Wolverhampton. ORCID ID: 0000-0002-9985-0827. Dr Potočnik also sits on the Board of Directors to The F-List for Music (CIC), https://thef-listmusic.uk/.
} 
"Representation of the world, like the world itself, is the work of men; they describe it from their own point of view, which they confuse with the absolute truth."

Simone de Beauvoir ${ }^{1}$

\section{INTRODUCTION}

The Covid-19 pandemic has stopped all live music. Albeit the closure was temporary, the way in which we consume music has substantially shifted for all generations. The new way is, finally, streaming. Users can access their favourite songs at any time they wish to, by simply logging into their streaming service profile (i.e. interactive streaming). ${ }^{2}$ When wishing for a session of music listening without interruptions, users might pay a subscription fee (usually monthly), although a payment of such a fee is not a requirement to access the music in all cases (i.e. free streaming services). Interactive streaming is different to downloading a track, or a single song, because the consumer will not "keep a copy."3

With the migration to online consumption of music, artists of all types were aiming to fill the gap caused by the (hopefully temporary) cancellation of live performances, with an income from streaming, which was used by all on an unprecedented scale. On a global scale, this is not the first time that streaming has 'saved' the music industry. ${ }^{4}$ When streaming first started, the music industries were in a downturn, caused by digital piracy resulting in lack of income. In Covid-19 times however, bar from some exceptions, music streaming income has not proven capable of paying the bills, for most artists.

Covid-19 is not the sole cause of the streaming problem. It is better viewed as a catalyst to pre-existing inequalities in the UK music industries. The first cause is the gender underrepresentation and inequality of women (i.e., all who identify as women), ${ }^{5}$ including gender minority artists, that have gone unchecked for many decades before, and have led to the exclusion of some women from certain sections of the music industries altogether; ${ }^{6}$ and led other women to refuse their participation in the mainstream industry. ${ }^{7}$

\footnotetext{
${ }^{1}$ As reproduced in Caroline Criado Perez, Invisible Women: Exposing Data Bias in a World Designed for Men (Chatto \& Windus, 2019) non-numbered page at the start.

${ }^{2}$ Christian L Castle and Claudio Feijóo, 'Study on the Artists in the Digital Music Marketplace: economic and legal considerations' (1 June 2021) Report to the WIPO Standing Committee on Copyright and Related Rights, Forty-first Session, Document Code: SCCR/41/3 ("WIPO Study"). Available: https://www.wipo.int/meetings/en/doc_details.jsp?doc_id=540735, 6-7. All hyperlinks in this article have been accessed on 10 August 2021.

${ }^{3}$ The legal nature of 'a stream' is a controversial issue, see Section 4.2. A recent WIPO Study (n2) 9-10 (recommends a sui generis view of a stream, which is different to a sale, license or a download, and should be remunerated with a new royalty, which is an additional payment from a streaming platform to the performer (i.e., streaming remuneration)).

${ }^{4}$ Streaming was seen as the main factor to the profit turnaround in 2019 (rising to a growth of $\$ 21.5$ billion, from a previous decline from \$24.4 billion in 2001 to \$14.2 billion in 2014: see Tony Rigg and Ann Harrison, 'Introduction: Music Law; Unravelling complexities (Tony Rigg) and The perspective of a legal practitioner' in Ann Harrison and Tony Rigg (eds), The Present and Future of Music Law (Bloomsbury Publishing, 2021) 5.

${ }^{5}$ The author defines "women" inclusively, to mean all, who identify as women (cis and trans) and all gender minority and/or nonbinary people.

${ }^{6}$ Further information on the exclusion of entire groups from the participation in the British Music Festivals reported in: Emma Webster and George McKay: 'From Glyndebourne to Glastonbury: The Impact of British Music Festivals' (2015) An arts and Humanities Research Council Funded Literature Review. Available: https://ahrc.ukri.org/documents/project-reports-andreviews/connected-communities/impact-of-music-festivals/. The authors' report "highlights the economic, social and cultural impact of British music festivals" and identifies a gap in our understanding of financials around the festivals: "there is a relative lack of literature about the impact of festivals on musicians, both in terms of the impact on how they tour but also the creative and economic impact of festivals."

${ }^{7}$ For example: Riot Grrrl groups, Ani DiFranco etc.
} 
In 2019 research reports finally provided the evidence of under-representation, ${ }^{8}$ which can no longer go ignored. Women and gender minority artists face systemic barriers, which hinder their professional success in the UK music industries. As will be seen from this article, the UK Department for Digital, Culture, Media \& Sport (DCMS) ${ }^{9}$ is yet to react to the gender inequalities in the sector. ${ }^{10}$ On an international level, the World Intellectual Organization Property (WIPO) made a shift in its approach in 2021, by placing the Gender Gap in Intellectual Property (IP) on its agenda and is actively looking into the existing barriers, with the aim of rectifying the systemic inequalities. ${ }^{11}$

The second cause 'of the streaming problem' is the lack of agency for individual or independent artists in all contract dealings, including profits to be distributed for streaming. ${ }^{12}$ Whilst this is a problem across the sector, it is further compounded for women and gender minority musicians. The way in which profits from streaming are distributed between the stakeholders is negotiated between the streaming services (e.g., Spotify, Apple Music); the record labels and the collective management societies (CMS) or organisations (CMOs) for the publishers' rights in songs. The record labels holding the most negotiating power, are the 'three Majors, ${ }^{13}$ which have the predominant market share. Even if the record labels represent the interests of their signed talent (an assumption which is not tested here), it becomes clear that with record labels in the UK signing mostly male talent, ${ }^{14}$ those with the seat at the table ${ }^{15}$ do not represent the interests of women or gender minority artists.

\footnotetext{
8 In UK for example: (1) Vick Bain, 'Counting the Music Industry: the Gender Gap' (2019) https://vbain.co.uk/research. (2) Linda Coogan Byrne \& Women in CTRL, 'Gender Disparity Data Report, An analysis of the Top 20 Most Played British Acts across British Radio Stations in the Period of June 2019-2020 and the Top 100 Radio Airplay chart in 2020' (2020) https://www.canva.com/design/DAEE37rIDuc/-7R8D7lzU7EMdcnv9Snw3w/view\#1. More broadly in the EU: Marilena Vecco et al, Gender gaps in the Cultural and Creative Sectors (with the exception of the audio-visual sector)' (European Expert Network on Culture and Audiovisual (EENCA) Report, 2019) http://www.eenca.com/eenca/assets/File/EENCA\%20publications/Final\%20Report\%20\%20Gender\%20in\%20CCS\%20EAC.pdf, 27 (equal pay issues in the EU markets).

${ }^{9}$ For more information: https://www.gov.uk/government/organisations/department-for-digital-culture-media-sport.

${ }^{10}$ For example, experts report that Artificial Intelligence, and specifically to this discussion, algorithms are not gender neutral. Christine Bauer and Andres Ferraro, 'Music recommendation algorithms are unfair to female artists, but we can change that' (30 March 2021) Conversation: https://theconversation.com/music-recommendation-algorithms-are-unfair-to-female-artists-but-wecan-change-that-158016. This is not something that the DCMS inquiry explored in detail. WIPO Study (n2) 30 (recognises the importance of recommendations tools in creating value in music streaming: "automatic or human-managed editorialization of services, the composition of playlists, the algorithms that decide the next title obviously play a major role in the creation of value and the possible royalties attached to it," but does not explore any bias that algorithms present, or the risks that might carry).

${ }^{11}$ The first of such gender-specific events was organized by WIPO on 28 April 2021, and will be followed by further action and events, focusing on, among other areas, the creative industries. WIPO, 'Closing the Gender Gap in Intellectual Property' (28 April 2021): https://www.wipo.int/women-and-ip/en/ and https://www.wipo.int/meetings/en/details.jsp?meeting_id=62770. WIPO does not (yet) follow a gender-specific approach in all of its studies or policies. In the streaming WIPO Study (n1) 15 (methodology refers to a sample "covering main typologies of artists and jurisdictions"), Annex: Artists Interviewed/Surveyed (authors present their sample, as interviews with 38 artists, who are divided in the following categories: (1) global artists (i.e., "defined as at least five top10 positions in home country official charts (Billboard, UK's Official Charts, etc.) spanning at least five years, plus at least three other countries official charts", (2) niche - pop, rock, electronic, (3) niche - classical, folk, jazz, instrumental, (4) national artists, (5) non-featured international (i.e., "they play for global artists or global emerging artists") and (6) independent artists. The artists are also divided geographically in (a) Africa, Asia, Latin America, (b) the EU and (c) Australia, Canada, UK and US. No further description of the sample (gender, race, age, sexual orientation, class, ...) is provided).

12 See Section 2.1.

${ }^{13}$ Sony, Universal and Warner. The market share for Sony and Warner stated in Tuneln Inc $v$ Warner Music UK Limited and Sony Music Entertainment UK Limited [2021] EWCA Civ 441 (Sir Geoffrey Vos, Lady Justice Rose and Lord Justice Arnold) [1] (per Arnold LJ) ("they account for more than half of the market for digital sales of recorded music in the United Kingdom, and about $43 \%$ globally).

${ }^{14}$ Bain (n8) 2 (the empirical evidence collected for example shows that "just over $14 \%$ of those currently signed to 106 music publishers and just under $20 \%$ of those signed to 219 record labels are female").

15 Women in CTRL, 'A Seat at The Table: Diversity in the Music Industry' (1 July 2020): https://www.womeninctrl.com/seatatthetable/. This report offers the analysis of the make-up of teams, board members, chairpersons and CEO positions across 12 UK music industry trade bodies in July 2020. The report finds that there is still underrepresentation of women and minorities in leadership positions in the UK music industries: for women: $27 \%$ of CEOs across
} 
The aim of this article is to expose the incomplete approach of the DCMS inquiry in collecting evidence about the effect of streaming on artists. The call for evidence was open in late 2020, inviting all interested stakeholders in submitting evidence. As will be shown through evidence overview, ${ }^{16}$ the evidence collected focused predominantly on stakeholders, which already have a seat at the table. The DCMS Committee did not, despite being notified of the need to do so, ${ }^{17}$ collect evidence from the groups of under-represented musicians in the UK. Relying on the theories of relational legal feminism ${ }^{18}$ and Intellectual Property and Social Justice (IPSJ), ${ }^{19}$ it is argued here that treating all artists as 'one' or a 'homogeneous' group, works in favour of the pre-existing default musician, who is male, and most-oft, white. This is not inclusive and should be avoided in future legislative inquiries into the legal framework aimed at the UK music industries.

This article will explore the background that led to the DCMS inquiry into the Economics of Music Streaming in 2020, together with a detailed overview of the terms of the inquiry and evidence collected (Section 2). Next, the article offers a feminist framework for a review of any IP rules or practices and argues for an evidenced based approach to any proposed reform (Section 3). The IP rules on streaming are explored next (Section 4), before this article concludes with a fundamental recommendation for future legislative inquiries in the UK music industries (Section 5). Refusing to engage with systemic barriers that women and gender minority artists face, in this, and future DCMS inquiries, ${ }^{20}$ will damage the inclusivity, fairness and success of all musicians in the UK, aiming to recuperate after the devastation of the Covid-19 pandemic. Inclusivity must be a legislative choice if we are to "build back better." 21

\section{CASE STUDY: THE DCMS INQUIRY ON THE ECONOMICS OF MUSIC STREAMING}

\section{a. Background and Issues}

The unfairness of the streaming model in the UK was brought to light by the Covid-19 pandemic, but the problems of the system predate the pandemic. In April 2020, the musician and director of the Ivors Academy, Tom Gray, tweeted \#BrokenRecord, explaining the faulty system under

\footnotetext{
11 music trade body board; 9\% of chairpersons across 11 music trade body boards (with 1 female chair across 11 trade bodies from this report); $34 \%$ of board members across 12 music trade body boards; and $6 \%$ as the lowest gender representation of women on the PPL Board. For black women, there is further underrepresentation: $0 \%$ of CEOs; $0 \%$ of chairpersons; $3 \%$ of board members; and $2 \%$ employed in team or executive team across 12 music trade body boards (with 2 positions held out of possible 118 positions). An updated report is available for 2021 (published in July '21): https://www.womeninctrl.com/seatatthetable2021/. ${ }^{16}$ See Section 2.3.

17 Submission EMS0119: The F-List for Music CIC, prepared by Vick Bain and Dr Metka Potočnik (submitted 16 November 2021; published 21 January 2021): https://committees.parliament.uk/writtenevidence/15265/pdf/.

${ }^{18}$ See Section 3.

${ }^{19}$ See Section 3.

${ }^{20}$ See Section 5. An ongoing DCMS inquiry, which is connected to the issues discussed in this article, and where issues of gender under-representation have been notoriously exposed in the media, is the DCMS inquiry "The Future of UK music festivals," available: https://committees.parliament.uk/work/779/the-future-of-uk-music-festivals/. For reports of under-representation of women on UK festival line-ups, already in 2017, musician Emma Lee Moss, and reported by the BBC (22 June 2017) https://www.bbc.co.uk/news/uk-england-40273193. And more recently, despite the active criticism of this practice, in 2021: Deborah Stinton, 'Turn Up The Volume - Female Focus' (March 2021), available: https://thef-listmusic.uk/turn-up-the-volumefemale-focus/.

21 In the UK, this is the Government's Plan for Growth (published 3 March 2021): https://www.gov.uk/government/publications/build-back-better-our-plan-for-growth. According to the UK Government, "Build Back Better: our plan for growth' sets out the government's plans to support growth through significant investment in infrastructure, skills and innovation, and to pursue growth that levels up every part of the UK, enables the transition to net zero, and supports our vision for Global Britain."
} 
which the UK musicians get paid. ${ }^{22}$ This was picked up and endorsed in May 2020 by the Musicians Union, ${ }^{23}$ and reported widely in the media. ${ }^{24}$ The campaign finally found favour also with the UK Government, which reacted in October 2020 by opening a DCMS legislative inquiry on the Economics of Music Streaming. ${ }^{25}$ The call for evidence was open until 16 November 2020 and the first hearings began already on 24 November $2020 .{ }^{26}$ Since then, the inquiry and the future of streaming has received ample attention in the media, and on social media platforms. ${ }^{27}$ As of June 2021, the discussion online remains active. ${ }^{28}$

Started on 12 April 2020, the \#BrokenRecord campaign, spearheaded by Tom Gray, ${ }^{29}$ focused on several aspects of the music industry, which in the Covid-19 environment represent a survival threat to many musicians in the UK. First, this is not a new problem, and the unfairness of profit sharing and the lack of transparency in record label deals predates the 2020 pandemic. Record label deals are often not favourable to the signed artists, and this is exacerbated in the

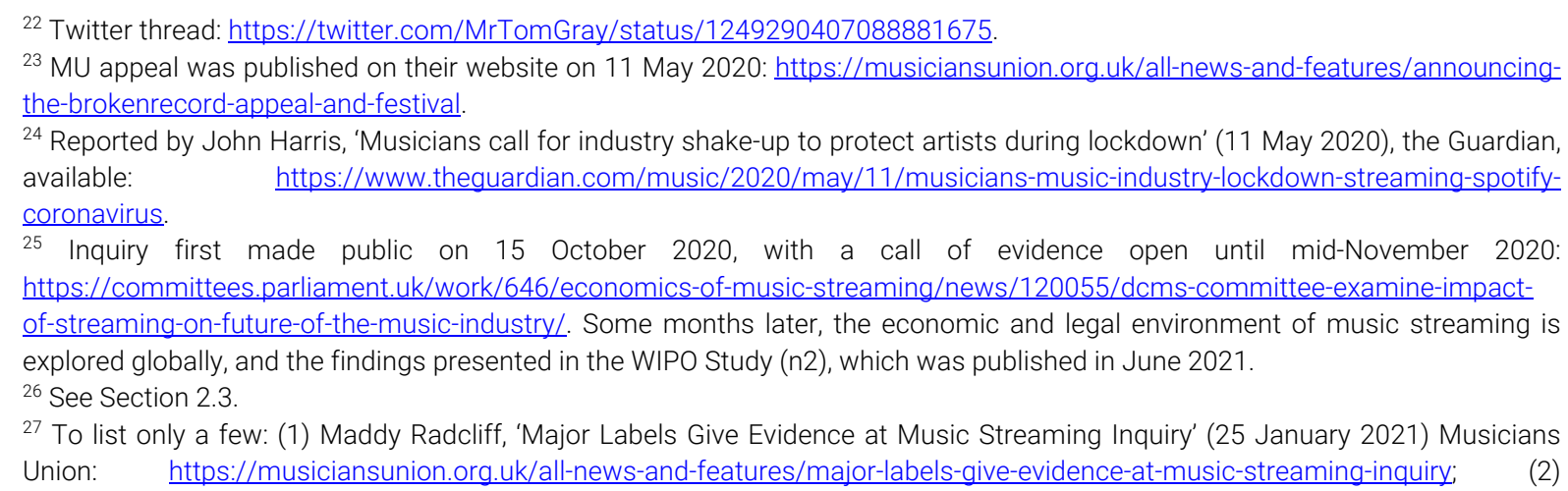

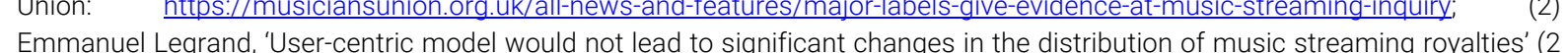
February 2021) Legrand Network: http://legrandnetwork.blogspot.com/2021/02/user-centric-model-would-not-lead-to.html; (3) Mark Sutherland, 'What does the DCMS Committee's streaming inquiry really mean for music makers?' (4 February 2021) Audio Media International: https://audiomediainternational.com/what-does-the-dcms-committees-streaming-inquiry-really-mean-formusic-makers/; (4) Micah Singleton, 'SoundCloud to Let Fans Pay Artists Directly: Exclusive' (5 February 2021) Billboard: https://www.billboard.com/articles/business/9522066/soundcloud-payout-system-fans-artists-direct-payments/; (5) Paul Donoughue, 'A music streaming inquiry in the UK raises questions about where your subscription dollars go' (11 February 2021) ABC News: https://www.abc.net.au/news/2021-02-12/uk-streaming-inquiry-peaks-under-the-hood-of-the-musicbusiness/13143718; (6) Rhian Jones, 'Songwriters fight to be heard in streaming revenues debate' (12 February 2020) The Guardian: https://www.theguardian.com/music/2021/feb/12/songwriters-fight-to-be-heard-in-streaming-revenues-debate; (7) Daniel Antal, Amelia Fletcher and Peter Ormosi, 'Music Streaming: Is It a Level Playing Field?' (23 February 2021) Competition Policy International: https://www.competitionpolicyinternational.com/music-streaming-is-it-a-level-playing-field/; (8) Jonathan Horsley, 'New report warns that independent music artists are being squeezed out of streaming revenues' (February 2021) musicradar: https://www.musicradar.com/news/new-report-warns-that-independent-music-artists-are-being-squeezed-out-of-streamingrevenues; (9) Tim Ingham, 'Slowly but Surely, The Major Labels' Dominance of Spotify is Declining' (1 March 2021) Music Business Worldwide: $\quad$ https://www.musicbusinessworldwide.com/slowly-but-surely-the-major-labels-dominance-of-spotify-isdeclining/\#: : text=Slowly\%20but\%20surely\%2C\%20the\%20major\%20labels $\% 20$ dominance\%20of\%20Spotify $\% 20$ is $\% 20$ declining,March\%201\%2C\%202021\&text=By\%202030\%2C\%20some\%20analysts\%20suggest,worth\%20more\%20than\%20\%24300\%20billio n.\&text=That's\%20music\%20streams\%3B\%20Spotify\%20makes,exempt\%20podcasts\%20from\%20this\%20calculation; and (10) on 20 April 2021, over 150 musicians signed a letter to the Prime Minister Johnson in support of the campaign and requested a change to the existing streaming system (\#FixStreaming, \#BrokenRecord), available for viewing and download: https://twitter.com/MrTomGray/status/1384416974919307264. As reported on 7 June 2021, the letter was sent to the PM, with a remarkable number of 234 signatories: https://twitter.com/MrTomGray/status/1401800931591741445.

${ }^{28}$ To illustrate, Crispin Hunt (Chair of the Ivors Academy and Director of PRS for Music) actively called on Apple Music and Amazon Music to raise the fees they are charging for music streaming (new models), coupled with a new business model, which would allocate more revenue towards the artists and musicians (Twitter, 17 May 2021): https://twitter.com/crispinhunt/status/1394371553694035971. On 7 June 2021, the Rolling Stones, Tom Jones and Yoko Ono added their signatures to the letter to the Prime minister Johnson (see footnote 27), calling for a change music streaming laws: Sam Shead, 'The Rolling Stones, Tom Jones and Yoko Ono urge UK to change music streaming laws' (CNBC, 7 June 2021), available: https://www.cnbc.com/2021/06/07/musicians-urge-uk-to-change-streaming-laws.html.

${ }^{29}$ For the first Tweet, see: https://twitter.com/MrTomGray/status/1249290407088881675 and for a further explanation and a talk, visit: https://musically.com/2020/05/18/brokenrecord-its-about-saying-we-all-recognise-that-this-is-problematic/. 
streaming environment, where the record labels earn up to $57 \%$ of the streaming profits, ${ }^{30}$ with unclear assignment of profit to the artist thereafter. Artists' fees therefore fall within the $57 \%$, which is distributed according to any contractual arrangements between the record label and the artist. Second, the songwriters are not adequately rewarded as they are allocated a fraction of the profits, when compared to the record labels. Song writers, who are the owners of copyright in the composition, are allocated only $13 \%$ of streaming profits, which is not proportionate to the profits assigned to the record labels, who are owners of rights in recordings (soundtracks). The creative input of songwriters and composers is therefore undervalued in the current economics of music streaming. The under-valuation of song is however a pre-Covid-19 unfairness of the system.

Against this background the \#BrokenRecord campaign called for government and/or industry action to remedy the lack of balance in profit sharing between the publishers (owning copyright in the song) and the record labels (owning rights in recordings). The campaign and its allies seek to ensure, among other things, ${ }^{31}$ that the creative talent, or the musicians, who are beloved by their fans, start making money from their music, and in particular, start earning decent profits from music streaming. As noted by Tom Gray, at the value of $£ 0.005$ per stream, even artists with millions of streams will not earn a significant amount,

"There's dozens and dozens of young artists coming to me on Twitter every day going 'I've got however many million plays, I have two hundred thousand monthly listeners, I do not make minimum wage'... There's not enough money coming through to the artists in half of the label deals that are out there, however they're being done." 32

Put differently, at $£ 0.005$ per stream, and assuming the artists would earn $100 \%$ of the charge, a song would have to be played 1,782 times to amount to a single hour of the minimum wage rate in the UK. ${ }^{33}$ One year on, and the reports from the industry continue to criticise heavily the economics of the system. ${ }^{34}$

\section{b. Terms and Conditions of the Inquiry}

The DCMS Committee invited written submissions to the Economics of Music Streaming inquiry by an online call, published on 15 October 2020, with a one-month deadline. This call was shared by many of the business and professional organisations in the UK music industries, but it is difficult to assess how many artists were aware of this legislative call. The F-List for Music CIC, representing the interests of women and gender minority artists, submitted a general position paper calling for a further empirical stage, collecting the much need gender

\footnotetext{
${ }^{30}$ The remaining $30 \%$ of profits are allocated to the streaming services.

${ }^{31}$ The \#BrokenRecord exposed other inequalities in the system, which reach beyond music streaming and this article. The campaign however does not highlight the differences for different artists, and in particular does not differentiate between the artists based on gender, race, age, ability, class or another personal characteristic.

${ }^{32}$ Shared by Tom Grady on 11 May 2021: https://musically.com/2020/05/18/brokenrecord-its-about-saying-we-all-recognise-thatthis-is-problematic/. For a systemic overview of per-stream rates, for different artists, see WIPO Study (n2) Annex: Per Stream Rates for Selected Artists (ranging in 2020 from $€ 0.00009$ to $€ 0.00433$, which led to a total artist's pay-out in these two cases, for that year between $€ 1.17$ and $€ 3,467)$.

${ }^{33}$ In April 2021, it is $£ 8.91$ (for over 23) and less for younger workers: https://www.gov.uk/national-minimum-wage-rates.

${ }^{34}$ Lanre Bakare, 'The music streaming debate: what the artists, songwriters and industry insiders say' (10 April 2021) Guardian: https://www.theguardian.com/music/2021/apr/10/music-streaming-debate-what-songwriter-artist-and-industry-insider-saypublication-parliamentary-report.
} 
specific data on the present issues. ${ }^{35}$ The F-List and its representatives were not invited to give oral evidence or collect further empirical data.

The DCMS Committee set out to examine the impact of music streaming on several stakeholders, including artists and record labels, in light of the sustainability of the wider music industry. Acknowledging that streaming at present accounts for more than half of the global music industry's revenue, the DCMS Committee intended to investigate business models in operation at streaming service providers (or platforms) such as Spotify, Apple Music, Amazon Music and Google Play). According to the DCMS Committee, music streaming in the UK "brings in more than $£ 1$ billion in revenue with 114 billion music streams in the last year, however artists [songwriters] can be paid as little as $13 \%$ of the income generated." 36

In related context, the DCMS also set out to investigate any action needed by the Government to "protect the industry from the piracy in the wake of the steps taken by the EU on

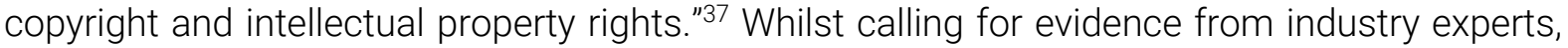
artists, record labels and the streaming platforms, the Terms of Reference ${ }^{38}$ included the following questions to be considered in written submissions:

"1. What are the dominant business models of platforms that offer music streaming as a service?

2. Have new features associated with streaming platforms, such as algorithmic curation of music or company playlists, influenced consumer habits, tastes, etc?

3. What has been the economic impact and long-term implications of streaming on the music industry, including for artists, record labels, record shops, etc?

4. How can the Government protect the industry from knock-on effects, such as increased piracy of music? Does the UK need an equivalent of the Copyright Directive?

5. Do alternative business models exist? How can policy favour more equitable business models?"

The full report or outcome of the legislative inquiry has been published in July 2021, and Kevin Brennan MP presented the Music Streaming Bill to the House on 16 June 2021, with the Second Reading debate scheduled for 3 December 2021. ${ }^{39}$ The focus of this article is not the outcome of this legislative inquiry (which was concluded after the writing of this article - see Section VII), rather the process or method in which the DCMS Committee collected evidence that informed its 'evidence-based' recommendations.

\section{c. Evidence Review: the Gender Blindspot}

The DCMS Committee collected both written, and oral evidence in the course of its inquiry. ${ }^{40} \mathrm{As}$ will be seen from the overview here, there was no effort made to collect evidence from artists

\footnotetext{
${ }^{35}$ Submission for The F-List (n17).

36 Stated in the general inquiry description: https://committees.parliament.uk/work/646/economics-of-musicstreaming/publications/.

${ }^{37}$ Reference at (n25)

${ }^{38}$ Stated in the Call for Evidence: https://committees.parliament.uk/call-for-evidence/273/economics-of-music-streaming/.

39 At the time of writing, the report has not yet been published on DCMS website (June 2021): https://committees.parliament.uk/work/646/economics-of-music-streaming/news/. The news was made public by Brennan on Twitter: https://twitter.com/KevinBrennanMP/status/1405170680300179461. For the recent update (July 2021), see post scriptum in Section VII.

${ }^{40}$ This article relies on publicly available written evidence, published by DCMS online. The article also relied on oral evidence, which was shown on Parliamentary TV, and is still available online: https://committees.parliament.uk/work/646/economics-of-music-
} 
and groups, which are demonstratively underrepresented in the UK music industries. Instead, the inquiry is led under the singular notion of 'an artist' as a homogeneous concept of 'a talented individual' worthy of protection. At best, there were distinctions made at times, between a 'signed' and 'independent;' or 'emerging' and 'well-established' artists. As seen from the inquiry question three, cited in the previous section, "economic impact and long-term implications of streaming on the music industry, including for artists" were posited in gender-neutral terms, with no consideration of specific characteristics, such as gender, race, age, disability, class or other personal characteristic. This deliberate choice, however, is not without negative consequences. Feminist scholarship unequivocally shows ${ }^{41}$ that such assumptions and default categories are rarely inclusive and considerate of various characteristics of individuals, covered by a policy or practice.

Written evidence submitted to the DCMS Committee, which was made available for public viewing, was released online in increments. ${ }^{42} \mathrm{~A}$ majority of submissions were submitted with the initial call in November 2020 and published online in January 2021. When the Committee requested further clarification to be made from certain witnesses and organisations, these were published online between 11 February and 20 April 2021. In total, there are two hundred and thirteen written submissions recorded online, all logged with an individual number. Three submissions were published on 24 November 2020; one on 22 January 2021; one on 11 February 2021; three on 23 February 2021; one on 2 March 2021; six on 23 March 2021; and four on 20 April 2021. The remaining one hundred and fourteen written submissions were published and shared with the public on 21 January 2021.

Out of the two hundred and thirteen written submissions, fifty-one were submitted by companies and organisations, which have not listed any persons $(23,94 \%)$. Based on names, and online search of public records, the remaining written submissions were allocated in groups, where at least one woman is named on the submission; and contrasted with groups, where only men have been listed on the written submission. Out of the remaining one hundred and sixty-two submissions, thirty-two included at least one woman (19.75\%), with four submissions making the gender determination of authors impossible $(2.47 \%) .{ }^{43}$ The remaining one hundred and twenty-six submissions listed at least one, or more men (77.78\%). In total, women are listed on $15 \%$ of all written submissions (appearing at least as a co-author). ${ }^{44}$

The DCMS Committee exercised its discretion in selecting the witnesses it invited to give oral testimony. The Committee had twelve members, out of which three are women $(25 \%) .{ }^{45}$ There were seven hearings in front of the Committee, in which thirty-four witnesses were heard. ${ }^{46}$ Out of those, nine witnesses were women (26.47\%). In hearing on 24 November 2020, the Committee took evidence from artists, musicians, managers and music accounting

streaming/. Private or confidential exchanges made with the DCMS Committee are not included in this section (i.e., restricted access).

${ }^{41}$ See Section 3.

42 Written submissions published online are available: https://committees.parliament.uk/work/646/economics-of-musicstreaming/publications/written-evidence/.

${ }^{43}$ Submissions EMS0199 (anonymous); EMS0268 (singed by Princess); EMS0262 (signed by Hamilton); and EMS0290 (submitted by Apple and signed by "Sam").

${ }^{44}$ Written submissions, which include at least one named female author: EMS0011, EMS0029, EMS0041, EMS0037, EMS0058, EMS0048, EMS0065, EMS0081, EMS0103, EMS0119, EMS0115, EMS0112, EMS0106, EMS0124, EMS0148, EMS0136, EMS0160, EMS0159, EMS0171, EMS0169, EMS0168, EMS0195, EMS0205, EMS0198, EMS0225, EMS0254, EMS0260, EMS0070, EMS0149, EMS0286, EMS0288, and EMS0289.

${ }^{45}$ DCMS Committee Members: Julian Knight (Chair), Kevin Brennan, Steve Brine, Philip Davies, Alex Davies-Jones, Clive Efford, Juliet Elliott, Damian Green, Damian Hinds, John Nicolson, Giles Watling and Heather Wheeler.

${ }^{46}$ Sessions are available for viewing: https://committees.parliament.uk/work/646/economics-of-music-streaming/events/all/. 
experts. In this group, there were six witnesses, out of whom there was one woman (16.67\%). ${ }^{47}$ In its hearing on 8 December 2020, the Committee heard from six witnesses again, and this time, there were two women amongst them (33.33\%). These witnesses represented views from managers, collective management organisations (CMOs) and songwriters. ${ }^{48}$

In its third hearing, the DCMS Committee heard views from the CMOs (PPL ${ }^{49}$ and PRS for Music ${ }^{50}$ ) and the three major record labels. There were five witnesses on 19 January 2021, among which there was one woman (20\%). ${ }^{51}$ In its next hearing on 4 February 2021, the Committee took evidence from independent labels. Out of the three witnesses heard on the day, one was a woman (33.33\%). ${ }^{52}$ When hearing from representatives of the publishers, professional bodies in the industry and streaming services providers, the Committee heard seven witnesses on 10 February 2021. Out of the seven, one was a woman (14.29\%). ${ }^{53}$

In the remaining two hearings, the DCMS Committee heard representatives from streaming service providers and the Government. On 23 February 2021, the Committee took evidence from three witnesses, out of whom there was one woman (33.33\%). ${ }^{54}$ In its last hearing, the Committee heard from four witnesses, two of whom were women (50\%). Both women were governmental representatives. ${ }^{55}$

In sum, the inquiry has seen women represented on $15 \%$ of all written evidence submitted to the inquiry; and represent $26.47 \%$ of all witnesses heard (there were nine women out of thirty-four witnesses heard).

\section{FEMINIST TOOLBOX: THEORY AND METHOD}

Music streaming is governed by IP rights existing in a song and its recording. Much of IP scholarship offers a range of theoretical approaches to IP rights, which question the extent of rights to be given to individuals. Justifications of IP rights are varied, and yet, only seldom rely

\footnotetext{
47 Witnesses heard on 24 November 2021: (1) Tom Frederikse (Clintons Solicitors); (2) Tom Gray (musician with Gomez, \#BrokenRecord, PRS); (3) Colin Young (CC Young \& Co)); (4) Guy Garvey (musician with Elbow, BBC presenter); (5) Ed O’Brien (musician with Radiohead); and (6) Nadine Shah (musician).

48 Witnesses heard on 8 December 2021: (1) Maria Forte (Maria Forte Music Services Ltd); (2) Kwame Kwaten (Ferocious Talent); (3) José Luis Sevillano (Artistas Intérpretes o Ejecutantes); (4) Fiona Bevan (singer, song writer); (5) Soweto Kinch (Jazz saxophonist, MC and composer); and (6) Nile Rodgers (song writer, producer and artist).

${ }^{49}$ UK's Music Licensing Company for Performers and Recording Rightsholders: https://www.ppluk.com/.

${ }^{50}$ PRS for Music consists of two CMOs: The Performing Right Society (PRS) and the Mechanical-Copyright Protection Society (MCPS): https://www.prsformusic.com/.

${ }^{51}$ Witnesses heard on 19 January 2021: (1) Peter Leathem (PPL); (2) Andrea Martin (PRS for Music); (3) Tony Harlow (Warner Music UK); (4) Jason Iley (Sony Music UK \& Ireland); and (5) David Joseph (Universal Music UK).

52 Witnesses heard on 4 February 2021: (1) Yvette Griffith (Jazz Re:freshed); (2) Paul Pacifico (Association of Independent Music); and (3) Rupert Skellett (Beggars Group).

${ }^{53}$ Witnesses heard on 10 February 2021: (1) Roberto Neri (Music Publishers Association); (2) Geoff Taylor (BPI); (3) Graham Davies (Ivors Academy); (4) Horace Trubridge (Musicians Union); (5) Steve Bené (Twitch); (6) Raoul Chatterjee (Soundcloud); and (7) Katherine Oyama (YouTube).

${ }^{54}$ Witnesses heard on 23 February 2021: (1) Paul Firth (Amazon Music); (2) Horacio Gutierrez (Spotify); and (3) Elena Senegal (Apple Music).

55 Witnesses heard on 22 March 2021: (1) Caroline Dinenage (DCMS); (2) Robert Specterman-Green (DCMS); (3) Tim Moss (Intellectual Property Office); and (4) Amanda Solloway MP (Minister for Science, Research and Innovation, Department for Business, Energy and Industrial Strategy).
} 
on feminist understanding of the law. The literature is more extensive in the United States, ${ }^{56}$ and some feminist scholarship on IP law is now starting to emerge in the UK as well. ${ }^{57}$

Embedded in the broader framework of Intellectual Property and Social Justice (IPSJ), ${ }^{58}$ this paper follows a broader body of work, ${ }^{59}$ which investigates IP regimes from a feminist perspective. IPSJ informed approach to IP law does not mandate the relinquishment of all IP rights. To the contrary, IP law is used in order to increase access, empowerment and inclusion of the under-represented creative groups. ${ }^{60}$ In combination with feminist theory this paper advocates against a gender-neutral approach (i.e. a neutral, or 'objective' stance) to the category of 'artist,' 'musician,' 'creative,' or 'a talented individual' without appreciating the intersectionality of personal characteristics these individuals possess, which might affect their individual circumstances. Informed by relational legal feminism, ${ }^{61}$ it is argued that the focus of IP law should shift from 'outputs' to 'individuals:' that is, the focus should be on the 'artists' as human beings of multitude qualities. Relational legal feminism places the attention on human beings, not only as 'value' or 'output' creators, but as individuals, worthy of knowing, as they demonstrate multiple qualities and perspectives. ${ }^{62}$

The combination of social justice and feminist theory allows researchers in IP law and the music industries to investigate the effect of IP laws and related practices on multiple artists and creatives in the industry and move away from any default assumptions of 'an artist' as a homogenous concept, or an individual with a set of uniform qualities. This means that the current approach to the link between a 'talented individual' that creates 'outputs' and deserves protection in law (IP law) is too broad and feminist inquiry mandates that individual experience of women and gender minority artists be explored in more detail. The DCMS in the Creative Sector Deal refers to creators in gender neutral terms, or sometimes refers to even a passive "supply and diversity of skills and talent in the creative industries."63

Feminist (substantive) theory is to be complemented with the theory of positionality to construction of feminist knowledge ${ }^{64}$ and feminist methods of inquiry (i.e., Feminist Toolbox). Feminist Toolbox includes methods of intersectionality, consciousness raising, raising

\footnotetext{
${ }^{56}$ Argument and approach first explored in Metka Potočnik, 'Exposing Gender Bias in IP: The Music Industry' (30-31 October 2020) Sixth Annual IP Mosaic Conference: The Arc is Hot! Using IP to Further Social Justice: https://iipsj.org/programs/ip-mosaic/; and Metka Potočnik, 'Exposing Gender Bias in Intellectual Property Law: The Music Industries' in Steven D Jamar and Lateef Mtima (eds), Handbook of Intellectual Property and Social Justice: Access, Inclusion, Empowerment (Cambridge University Press, forthcoming 2021).

57 Potočnik (2020) (n56). A recent OUP open access handbook: Irene Calboli and Maria Lillà Montagnani (eds), Handbook of Intellectual Property Research: Lenses, Methods and Perspectives (OUP, 2021) hosts chapters from IPSJ, Critical Race Theory (CRT) and feminist IP scholars: (1) Lateef Mtima and Steven D Jamar, 'Researching Social Justice Aspects of Intellectual Property' (Chapter 42); (2) Anjali Vats and Deidré A Keller, Critical Race Theory as Intellectual Property Methodology' (Chapter 48); (3) Ann Bartow, 'Feminist Methodologies and Intellectual Property' (Chapter 47). This book can be downloaded (pdf) here: https://global.oup.com/academic/product/handbook-of-intellectual-property-research-9780198826743?cc=gb\&lang=en\&.

58 Lateef Mtima, 'IP Social Justice Theory: Access, Inclusion, and Empowerment' (2019) 55 Gonz L Rev 401; and for a systemic overview: Steven D Jamar and Lateef Mtima (eds), Handbook of Intellectual Property and Social Justice: Access, Inclusion, Empowerment (Cambridge University Press, forthcoming 2021). IPSJ is put in practice by the Institute of Intellectual Property and Social Justice: https://iipsj.org/.

${ }^{59}$ Argued and explained in detail in Potočnik (2020) (n56) and Potočnik (forthcoming 2021) (n56).

${ }^{60}$ Mtima (n58); and Jamar and Mtima (n58).

${ }^{61}$ Robin West, 'Relational feminism and law' in Robin West and Cynthia Grant Bowman (eds), Research Handbook on Feminist Jurisprudence (Edward Elgar, 2019) 70 ("explaining the shift that this theory offers in the following terms "[t]here is much that is wrong, that is inhuman and cruel, about our idealized liberal vision of unencumbered souls marching through chosen lives of productivity and earned incomes unencumbered by human connection. Feminism can be and has been a way to highlight what is wrong with such a vision and to seek a more humane and inclusive ideal for communal life").

62 West (n61).

${ }^{63}$ Creative Industries Sector Deal (DCMS, 2018): https://www.gov.uk/government/publications/creative-industries-sector-deal, 8.

${ }^{64}$ Bartlett explains the theory of positionality as the appreciation of multiple perspectives in constructing knowledge, moving away from universal, objective or default "truths:" Katharine T Bartlett, 'Feminist Legal Methods' (1990) 103 Harv L Rev 829, 832.
} 
awareness or asking the women question. ${ }^{65}$ The lived experience of women and gender minority artists can be collected through various forms, including interviews, testimonials, or multi-method approach through the arts (art-based research) ${ }^{66}$ It is argued here that multiple perspectives will enrich the discussion and should not be avoided in any future inquiry into the music (or other creative) industries in the UK. These methods of evidence collection have not been considered by the DCMS Committee and the Final Report does not mention gender, or women musicians at all (see Section VII), ignoring all industry reports of gender underrepresentation in the sector.

\section{INTELLECTUAL PROPERTY RIGHTS IN MUSIC STREAMING}

IP rights associated with songs and music are complex, and regimes to access benefits arising from these creative works often represent know-how which artists learn to appreciate during their careers: either by learning through mistakes, or through the benefits of expert representation and support. Multiple projects attempted to dispel the mystique surrounding IP rights in music, and one such helpful example is the Guide on Music Copyright, ${ }^{67}$ commissioned by the UK Intellectual Property Office in 2021.

Rules governing music streaming are not only complex, but they also further lack transparency or international harmonisation. Although streaming is global and online, spanning across the internet without borders, legal rights associated with music streaming remain territorial. Even more, compared to broadcasting rights, fewer rules are set on an international level, and discretion rests with each state to regulate this area of music copyright exploitation. With Brexit, ${ }^{68}$ the UK has the option to set rules, which could be inclusive, fair and offer just remuneration to the artists and creatives responsible for music creation. With such freedom, however, also comes responsibility to get it right, and as artists' campaigns (i.e., \#BrokenRecord or \#FixStreaming) demonstrate, so far, streaming is not rewarding artists fairly. ${ }^{69}$

\section{a. IP Rights on Radio and in Streaming}

Without songs, there would be no music streaming. A point that was much stressed by song writers and their representatives in the DCMS inquiry. Why therefore is there further talk of other industry actors? This is because not only is the musical composition, and its lyrics (should they be written) awarded copyright, but there is a separate copyright awarded in sound recordings of such songs. Here, copyright is awarded to the producer, or the organisation, that has made the recording possible. It is here we often see the introduction of the record label, recording the song in the form of a sound recording, phonogram or a 'track.'

Rights granted in songs, when played in public, are regulated on international; and detailed in domestic legal frameworks. ${ }^{70}$ On the international level, relevant rules can now be

\footnotetext{
${ }^{65}$ For overview, see Bartlett (n64) 837 (asking the woman question), 851 (feminist practical reasoning), 857 (still a rational approach), 866 (consciousness raising as meta-method).

${ }^{66}$ Patricia Leavy, Method Meets Art; Art-Based Research Practice (Third Edition, The Guilford Press, 2020). In chapter four, Leavy explores music as method of research, which would be of particular interest to researchers in the music industries.

${ }^{67}$ Guide 'Music Copyright Explained' (2021) commissioned by the Intellectual Property Office, produced by CMU Insights, available: https://musiccopyrightexplained.com/ (downloadable pdf guide).

${ }^{68}$ Transition period ended on 31 December 2020: https://www.gov.uk/transition.

${ }^{69}$ See Section 3. For an overview of artists' campaigns in France and the US, see WIPO Study (n2) 15-16.

${ }^{70}$ For overview of the UK legislative framework, see Tuneln v Warner (n13) (Sir Geoffrey Vos, Lady Justice Rose and Lord Justice Arnold) [43]-[58]. The Court of Appeal's decision confirmed partially on s.20 CDPA, appeal allowed in part, with regards to s.17 CDPA and recording in Warner Music UK Ltd v TuneIn Inc [2019] EWHC 2923 (Ch) (Justice Birss).
} 
found in the Berne Convention, ${ }^{71}$ the Rome Convention, ${ }^{72}$ the WIPO Copyright Treaty (WTC), ${ }^{73}$ and the WIPO Performances and Phonograms Treaty (WPPT). ${ }^{74}$ The Berne Convention has been incorporated into the World Trade Organization's (WTO) Agreement on Trade Related Aspects of Intellectual Property Rights (TRIPS) ${ }^{75}$ and is binding, as a covered agreement, on all WTO Member States. ${ }^{76}$ On the regional level, the European Union adopted the Information Society Directive, ${ }^{77}$ and the Rental Right Directive, ${ }^{78}$ and most recently the Digital Single Market Directive (also referred to as the New Copyright Directive). ${ }^{79}$ The UK is a WTO Member State and is bound by all international rules referred to in this section. Regarding the regional rules of EU origin, the UK is obligated to follow only the rules of "EU-derived domestic legislation" or "retained EU case law"80 and not rules, which have been legislated by EU authorities after Brexit. ${ }^{81}$ The New EU Copyright Directive is not part of UK law.

Although the system does not clearly stipulate all rights associated with streaming, it does so with songs being played in public, and on the radio (so-called broadcast). The clarity of rights regulation of performance in public is also used as the model of future reform, in a recent WIPO Study on Streaming, published on 1 June 2021.82 The study reports on the unfairness of remuneration of music performers (featured and non-featured) in interactive streaming, which does not exist in remuneration systems for non-interactive streaming (e.g. webcasting or digital radio broadcasting), where royalties are determined by a tariff, which is set under national law. ${ }^{83}$ The Berne Convention ${ }^{84}$ provides authors' rights in musical works and sound recordings in

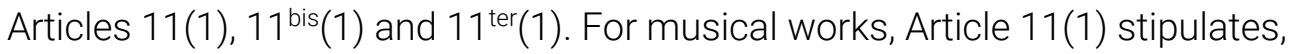

\footnotetext{
71 The International Convention for the Protection of Literary and Artistic Works signed at Berne on 9 September 1886 (Paris Act of 24 July 1971 as amended on 28 September 1979, to which the UK is a party). Available at WIPO: https://wipolex.wipo.int/en/treaties/textdetails/12214.

72 The International Convention for the Protection of Performers, Producers of Phonograms and Broadcasting Organisations agreed at Rome on 26 October 1961 (to which 96 states, including the UK, were party as at 15 September 2020). Available at WIPO: https://www.wipo.int/treaties/en/ip/rome/.

${ }^{73}$ The WIPO Copyright Treaty adopted in Geneva on 20 December 1996 (to which 109 states, including the UK, were party as at 25 January 2021). Available at WIPO: https://www.wipo.int/treaties/en/ip/wct/.

${ }^{74}$ The WIPO Performances and Phonograms Treaty (to which 108 states, including the UK, were party as at 25 January 2021). Available at WIPO: https://www.wipo.int/treaties/en/ip/wppt/.

${ }^{75}$ Art.2(2) of the Agreement on Trade-Related Aspects of Intellectual Property Rights (Annex 1C of the Marrakesh Agreement establishing the World Trade Organization, signed in Marrakesh, Morocco on 15 April 1994)1869 UNTS 299 (TRIPS).

${ }^{76}$ Art. 1 of the WTO, 'Understanding on rules and procedures governing the settlement of disputes' (Annex 2 of the WTO Agreement) (DSU Rules), available: https://www.wto.org/english/tratop_e/dispu_e/dsu_e.htm, referring to Appendix 1 to DSU Rules.

77 European Parliament and Council Directive 2001/29/EC of 22 May 2001 on the harmonisation of certain aspects of copyright and related rights in the information society ("the Information Society Directive"). Available on EUR-Lex: https://eurlex.europa.eu/legal-content/en/ALL/?uri=CELEX\%3A32001L0029.

${ }^{78}$ European Parliament and Council Directive 2006/115/EC of 12 December 2006 on rental right and lending right and on certain rights related to copyright in the field of intellectual property (codified version) ("the Rental Right Directive"). Available on EUR-Lex: https://eur-lex.europa.eu/legal-content/EN/ALL/?uri=CELEX\%3A32006L0115.

${ }^{79}$ Directive (EU) 2019/790 of the European Parliament and of the Council of 17 April 2019 on copyright and related rights in the Digital Single Market and amending Directives 96/9/EC and 2001/29/EC (Text with EEA relevance). Available on EUR-Lex: https://eur-lex.europa.eu/eli/dir/2019/790/oj. This new legislative solution in the EU, which is not adopted in the UK, was oft discussed in the DCMS inquiry, in particular for its proposal to revise the rules of Safe Harbour and their application to platforms such as YouTube, who do not pay the same royalties as the other streaming platforms. In addition, Articles 18 and 20 offer the right of appropriate and proportionate remuneration and contract adjustment mechanisms, which are relevant in the context of music streaming, which is at present not collectively managed by CMOs (in most countries).

80 Section 2-7 of the 2018 European Union (Withdrawal) Act, available: https://www.legislation.gov.uk/ukpga/2018/16/contents/enacted. The role of EU sources in the UK, after Brexit, which are relevant to the subject area of this article is further explored in Section 4.2. and the authorities cited therein.

${ }^{81}$ The Brexit Referendum took place on 23 June 2016. The UK left the EU on 31 January 2020, with the transition period ending on

31 December 2020

${ }^{82}$ WIPO Study (n2).

${ }^{83}$ WIPO Study (n2) 6-7, 22

${ }^{84}$ See (n71).
} 
"(1) Authors of dramatic, dramatico-musical and musical works shall enjoy the exclusive right of authorizing:

(i) the public performance of their works, including such public performance by any means or process;

(ii) any communication to the public of the performance of their works."

For literary and artistic works, the Berne Convention stipulates in Article 1 $1^{\text {bis }}$ (1),

"(1) Authors of literary and artistic works shall enjoy the exclusive right of authorizing:

(i) the broadcasting of their works or the communication thereof to the public by any other means of wireless diffusion of signs, sounds or images;

(ii) any communication to the public by wire or by rebroadcasting of the broadcast of the work, when this communication is made by an organization other than the original one;

(iii) the public communication by loudspeaker or any other analogous instrument transmitting, by signs, sounds or images, the broadcast of the work."

For literary works the Berne Convention additionally provides in Article 11 ${ }^{\text {ter }}$ (1),

"(1) Authors of literary works shall enjoy the exclusive right of authorizing:

(i) the public recitation of their works, including such public recitation by any means or process;

(ii) any communication to the public of the recitation of their works."

The Rome Convention ${ }^{85}$ regulates song rights for performers, producers of phonograms (or in UK terms, sound recordings) and broadcasting organisations. Specifically in Article 12 it gives the right of communication to the public to producers of phonograms, but such a right need not be exclusive, 86

"If a phonogram published for commercial purposes, or a reproduction of such phonogram, is used directly for broadcasting or for any communication to the public, a single equitable remuneration shall be paid by the user to the performers, or to the producers of the phonograms, or to both. Domestic law may, in the absence of agreement between these parties, lay down the conditions as to the sharing of this remuneration."

WCT ${ }^{87}$ was prepared by the Member States of the Berne Union in preparation for the changing digital environment. Specifically for performances of protected works, when an audience is not present, WCT defines the "right of communication to the public" in Article 8,

"Without prejudice to the provisions of Articles 11(1)(ii), 11bis(1)(i) and (ii), 11ter(1)(ii), 14(1)(ii) and 14bis(1) of the Berne Convention, authors of literary and artistic works shall enjoy the exclusive right of authorizing any communication to the public of their works, by wire or wireless means, including the making available to the public of their works in

\footnotetext{
${ }^{85}$ See (n72).

${ }^{86}$ Rome Convention, Art.16 (reservations).

${ }^{87}$ See (n73).
} 
such a way that members of the public may access these works from a place and at a time individually chosen by them." ${ }^{88}$

For sound recordings, producers are given additional rights in the new digital environment in WPPT. ${ }^{89}$ Article 14 WPPT does not mandate a granting of an exclusive right of communication to the public, ${ }^{90}$ but it does provide for the right of making available,

"Producers of phonograms shall enjoy the exclusive right of authorizing the making available to the public of their phonograms, by wire or wireless means, in such a way that members of the public may access them from a place and at a time individually chosen by them."

The EU Information Society Directive ${ }^{91}$ was also prepared in response to the changing digital environment and is purposively aligned with the international sources discussed so far. Specifically, the right of communication is regulated in Article 3, which is to be read together with the Directive's recitals, ${ }^{92}$

"1. Member States shall provide authors with the exclusive right to authorise or prohibit any communication to the public of their works, by wire or wireless means, including the making available to the public of their works in such a way that members of the public may access them from a place and at a time individually chosen by them.

2. Member States shall provide for the exclusive right to authorise or prohibit the making available to the public, by wire or wireless means, in such a way that members of the public may access them from a place and at a time individually chosen by them:

(a) for performers, of fixations of their performances;

(b) for phonogram producers, of their phonograms;

(c) for the producers of the first fixations of films, of the original and copies of their films;

(d) for broadcasting organisations, of fixations of their broadcasts, whether these broadcasts are transmitted by wire or over the air, including by cable or satellite.

3. The rights referred to in paragraphs 1 and 2 shall not be exhausted by any act of communication to the public or making available to the public as set out in this Article."

\section{Recital 15}

"The Diplomatic Conference held under the auspices of the World Intellectual Property Organisation (WIPO) in December 1996 led to the adoption of two new Treaties, the 'WIPO Copyright Treaty' and the 'WIPO Performances and Phonograms Treaty', dealing

\footnotetext{
${ }^{88}$ With the accompanying agreed statement in footnote 8 to Article 8: "It is understood that the mere provision of physical facilities for enabling or making a communication does not in itself amount to communication within the meaning of this Treaty or the Berne Convention. It is further understood that nothing in Article 8 precludes a Contracting Party from applying Article 11bis(2)."

${ }^{89}$ See (n74).

${ }^{90}$ WPPT, Art. 15 (reservations) grants the right of renumeration for broadcasting and making available right, given to performers and producers of phonograms.

${ }^{91}$ See (n77).

92 Tuneln v Warner (n13) [53] Arnold LJ helpfully explains the transposition of WIPO Treaties in the Information Society Directive ("It is clear from these recitals that Article 3(1) of the Information Society Directive gives effect to Article 8 of the WIPO Copyright Treaty, while Article 3(2)(b) of the Information Society Directive gives effect to Article 14 of the WIPO Performances and Phonograms Treaty").
} 
respectively with the protection of authors and the protection of performers and phonogram producers. Those Treaties update the international protection for copyright and related rights significantly, not least with regard to the so-called 'digital agenda', and improve the means to fight piracy world-wide. The Community and a majority of Member States have already signed the Treaties and the process of making arrangements for the ratification of the Treaties by the Community and the Member States is under way. This Directive also serves to implement a number of the new international obligations."

Recital 23

"This Directive should harmonise further the author's right of communication to the public. This right should be understood in a broad sense covering all communication to the public not present at the place where the communication originates. This right should cover any such transmission or retransmission of a work to the public by wire or wireless means, including broadcasting. This right should not cover any other acts."

Recital 27

"The mere provision of physical facilities for enabling or making a communication does not in itself amount to communication within the meaning of this Directive."

Aligned with international law, the Rental Right Directive, ${ }^{93}$ does not require EU Member States to grant exclusive rights of communication to the public to phonogram producers, rather it requires they be given single equitable remuneration. In Article 8(2) it states,

"Member States shall provide a right in order to ensure that a single equitable remuneration is paid by the user, if a phonogram published for commercial purposes, or a reproduction of such phonogram, is used for broadcasting by wireless means or for any communication to the public, and to ensure that this remuneration is shared between the relevant performers and phonogram producers. Member States may, in the absence of agreement between the performers and phonogram producers, lay down the conditions as to the sharing of this remuneration between them."

In the UK, the EU sources have been implemented in Section 20 of the CDPA. ${ }^{94}$ The interpretation of the exclusive right in Section 20 CDPA, which is "EU-derived domestic legislation," ${ }^{95}$ is still heavily influenced by CJEU case law, in particular decisions rendered by the CJEU before, or on 31 December 2020, as "retained EU case-law."96 The exclusive right of communication to the public and the right of making available in the UK is extended to phonograms (as per EU sources; or sound recordings, as per CDPA) ${ }^{97}$ Brexit has not changed

\footnotetext{
${ }^{93}$ See (n78).

${ }^{94}$ See more detail in Section 4.2. In the UK: The Copyright, Designs and Patents Act 1988. The Information Society Directive was transposed into UK law by the Copyright and Related Rights Regulations 2003, SI 2003/2498. Article 3 was implemented by Regulations 6 and 7, which, amongst other things, amended section 20 of the Copyright, Designs and Patents Act 1988.

${ }^{95}$ S. 2 of the 2018 Withdrawal Act (n80).

${ }^{96}$ S. 6 of the 2018 Withdrawal Act (n80).

97 Tuneln v Warner (n13) [57]-[58] (referring to ITV Broadcasting Ltd v TVCatchup Ltd (No 2) [2011] EWHC 1874 (Pat), [2011] FSR 40 at [49]-[79] (Floyd J); Football Association Premier League Ltd v QC Leisure (No 3) [2012] EWHC 108 (Ch), [2012] FSR 12 and
} 
the role of CJEU case law in understanding communication to the public within the wording of Section 20 CDPA; that is at least not until the provision is amended domestically, or there are specific reasons to depart from previous case law. ${ }^{98}$ The decision of Lord Justice Arnold in Tuneln v Warner is also instructive regarding CJEU decisions rendered after 31 December 2020:

"The CJEU has unrivalled experience in confronting this issue in a variety of factual scenarios. Moreover, it has developed and refined its jurisprudence over time. The jurisprudence is not free from difficulty or criticism, but it does not follow that better solutions are readily to hand." ${ }^{\text {99 }}$

When discussing IP protection online, questions of territoriality can become difficult to disentangle, seeing that the internet does not have a physical place. The courts have explained that all IP rights are territorial, which in the context of the internet, or for the purposes of this paper, music streaming, means, that copyright rights and protection in the UK under the CDPA is only triggered when the contentious act targets the UK (i.e., the need to establish a territorial link). ${ }^{100}$

In sum, IP rights in music played to the public are regulated more clearly for broadcasting (i.e., the radio). When played on the radio, the remuneration to the artists, publishers and the owner of rights in the sound recording are all fairly remunerated, and the collection of royalties is managed collectively. ${ }^{101}$ In contrast, there is less clarity regarding music

Dramatico Entertainment Ltd v British Sky Broadcasting Ltd [2012] EWHC 268 (Ch), [2012] RPC 27 at [52] and [64] (Arnold J - as he then was)).

${ }^{98}$ Tuneln v Warner (n13) [73] (Arnold LJ: "The departure of the UK from the EU on 31 January 2020 and the end of the implementation (or transitional) period under the UK-EU Withdrawal Agreement at 23:00 GMT on 31 December 2020 do not affect "EU-derived domestic legislation" such as section 20 of the 1988 Act as amended to implement the Information Society Directive: section 2(1) of the European Union (Withdrawal) Act 2018. Such legislation remains in effect unless and until it is repealed or amended") and [74] (and "Furthermore, 24 of the 25 judgments and orders of the CJEU listed in paragraph 67 above [in this article reproduced in footnote 37 below] constitute "retained EU case law" (section 6(7) of the 2018 Act), meaning that they continue to form part of domestic law post-Brexit and continue to bind lower courts: section 6(3) of the 2018 Act. The Court of Appeal and the Supreme Court have power to depart from such judgments and orders, but only on the same basis that the Supreme Court has power to depart from one of its own precedents or of one of the House of Lords in accordance with the Practice Statement (Judicial Precedent) [1966] 1 WLR 1234: section 6(5A) of the 2018 Act and the European Union (Withdrawal) Act 2018 (Relevant Court) (Retained EU Case Law) Regulations 2020 (SI 2020/1525)") and [90] (for CJEU cases decided after 1 January 2021 "Judgments of the CJEU given after 31 December 2020 do not form part of "retained EU law" and thus are not binding on any UK court or tribunal. A UK court or tribunal may nevertheless "have regard to" such judgments: section 6(2) of the 2018 Act;" these CJEU decisions can be applied by UK courts, if found convincing); and [144] (Arnold LJ clarifying, in the tension between intellectual property rights and freedom of expression, that "the EU Charter of Fundamental Rights is not part of retained EU law"), [183] (Lady Justice Rose cautions against restatement of CJEU principles, which are not directly engaged in the given case, and encourages courts to engage with future CJEU decisions, when points of law are further developed as per technology requirements in practice; this is to be done under the "may have regard" provision in s.6(2) of the 2018 Act), [201] (Sir Geoffrey Vos confirms the new judicial power to depart from CJEU case law ("EU retained law"), but only when "impeding nor restricting the proper development of the law, nor is it leading to results which are unjust or contrary to public policy" as is the law in general from departure from legal precedent: $R \vee$ National Insurance Commissioner: ex parte Hudson [1972] AC 944, 966 (as per Lord Reid)).

${ }^{99}$ Tuneln v Warner (n13) [80]. But see caution expressed by both Lady Justice Rose and Sir Geoffrey Voss against restating CJEU principles, when not warranted by the case facts themselves (n98)

${ }^{100}$ Tuneln v Warner (n13) [60] (Arnold LJ referring to CJEU case law: Case C-324/09 L'Oréal SA v eBay International AG [2011] ECR I-6011 (trade marks), Case 5-/11 Donner [EU:C:2012:370] (copyright) and Case C-173/11 Football Dataco Ltd v Sportradar GmbH [EU:C:2012:642] (database right); and applied in UK to communication to the public s.20 CDPA: EMI Records Ltd v British Sky Broadcasting Ltd [2013] EWHC 379 (Ch), [2013] Bus LR 884 ("EMI v BSkyB”); and in trade mark context: Merck KGaA v Merck Sharp \& Dohme Corp [2017] EWCA Civ 1834, [2018] ETMR 10 and Argos Ltd v Argos Systems Inc [2018] EWCA Civ 2211, [2019] Bus LR 1728), [61] (for summary of applicable legal principles on targeting).

101 See section 4.2. How does it work in practice? Musicians should register their songs as soon as they are created. In the UK, musicians should be aware of two databases: (1) The Database of Songs (administered by PRS). Registration and a searchable database available to musicians upon becoming PRS Members: https://www.prsformusic.com/works. Each song should be registered upon creation, and consequently the song receives a "unique tune code" which is a "Unique eight-digit code containing numbers and letters that's applied to each work when registered with PRS or MCPS." This registration ensures that "the work can 
streaming and the enforcement of IP rights associated with the commercial exploitation in music streaming is not managed collectively, at least not yet, or not in the UK. ${ }^{102}$ The payment for streaming is to be allocated to the owner of copyright in the song (original music composition) and the owner of copyright in the sound recording, both for the exclusive right of communication to the public. The payment and commercial exploitation are regulated through contracts, and not the CMOs which collect royalty payments for songs played on the radio.

\section{b. Commercial Exploitation: What is a Stream?}

DCMS inquiry clearly showed that the legal characterisation of 'a stream' is highly controversial in practice. This controversy is fuelled by the different consequences in commercialisation of IP rights in a song and its sound recording. Songwriters, artists and the CMOs are of the view that 'a stream' is analogous to a 'licence' and not a 'download or a sale.'103 This means that payment associated with each stream, or 'a listen' of a song on a streaming platform should be renumerated along the lines of remuneration rights associated with broadcasting and radio, and not those of CDs or other forms of album sales. Not surprisingly, representatives of record labels, held the view that 'a stream' is equivalent to a 'sale' whereas an artist, will be entitled to payments negotiated between, and regulated by a contract between their publisher and the artist. Remuneration will not be regulated collectively. Some industry representatives also renounced this dichotomy, positing that the legal character of 'a stream' is a complex issue, which does not have a relevant analogy in the present legal framework, consequently calling for a new, sui generis solution. ${ }^{104}$

In the UK, a stream would be qualified as a communication to the public, under Section 20 of the CDPA, ${ }^{105}$ and specifically, under the 'making available' right, which is an exclusive right given to copyright owners of musical, literary works and sound recordings,

"(1) The communication to the public of the work is an act restricted by the copyright in-

(a) a literary, dramatic, musical or artistic work,

(b) a sound recording or film, or

(c) a broadcast.

(2) References in this Part to communication to the public are to communication to the public by electronic transmission, and in relation to a work include-

(a) the broadcasting of the work;

\footnotetext{
be accurately identified whenever it is used. This ensures we collect and pay the correct royalties to the rightsholders and other interested parties." And the second database is (2) The Database of Recordings (administered by PPL). Here, each recording or a track should be registered when recorded, and consequently it will receive a ISRC code, which is unique to this track. PPL runs a searchable database, "The PPL Repertoire Search facility is designed for use primarily by PPL's licensees to search PPL's repertoire database for track information." Database is open, and available: https://repsearch.ppluk.com/ars/faces/pages/audioSearch.jspx?_adf.ctrl-state=8vaityrjv_4.

102 In the US a new collective management society has been established to manage rights in music streaming: The Mechanical Licensing Collective (operational since January 2021; established by the US Music Modernization Act 2018): https://www.themlc.com.

${ }^{103}$ See Section 2.3. for evidence overview: for example, evidence heard on 24 November 2020; and also, on 23 February 2021 (Elena Segal from Apple Music).

104 See Section 2.3. for evidence overview: for example, evidence heard on 23 February 2021 (Horacio Gutierrez from Spotify; Paul Firth from Amazon Music). Record label representatives clearly rejected the new sui generis proposal (in hearing on 19 January 2021).

${ }^{105}$ A position clearly presented to the DCMS inquiry by the representative of the UK Intellectual Property Office (Tim Moss, Chief Executive at IPO, heard on 22 March 2021).
} 
(b) the making available to the public of the work by electronic transmission in such a way that members of the public may access it from a place and at a time individually chosen by them."

In the UK this right has been influenced by EU copyright law extensively and the role of CJEU remains instrumental in understanding the boundaries of this economic rights (see previous section). CJEU case law is extensive ${ }^{106}$ and has held that the meaning of 'communication to the public' should be the same in the context of all EU Directives. ${ }^{107}$ Building on this case law and the current CJEU approach to a single concept of communication to the public, it is argued here that streaming would be interpreted under the current applicable principles, ${ }^{108}$ and no sui generis approach is to be developed separately in case law.

Despite the clarity of position in law that streaming is to be qualified as a communication to the public right under Section 20 CDPA, the barrier to a fair remuneration and recoupment of royalties for individual artists, who are not represented by record labels or other publishers, is the fact that the management system of a 'making available right' (i.e. for streaming) is not in the hands of collective societies, at least not as clearly as the 'broadcasting' rights (i.e. for radio), where royalties are transparently valued, negotiated, managed and distributed by CMOs to their members. Artists wishing to recoup their royalties for songs played on the radio, would have to register with (1) Performing Rights Society (PRS) for royalties of songs played on radio or TV (performance rights); (2) Mechanical-Copyright Protection Society (MCPS) for royalties in physical items (mechanical rights). ${ }^{109}$ Rights owners wishing to collect royalties associated with sound recordings will have to register with Phonographic

\footnotetext{
${ }^{106}$ Referenced in Tuneln v Warner (n13) [67] (Arnold LJ listing: Case C-306/05 Sociedad General de Autores y Editores de España (SGAE) v Rafael Hoteles SA [2006] ECR I-11519 ("SGAE"); Case C-136/09 Organismos Sillogikis Diacheirisis Dimiourgon Theatrikon kai Optikoakoustikon Ergon v Divani Akropolis Anonimi Xenodocheiaki kai Touristiki Etaireia [2010] ECR I-37 ("Organismos"); Case C393/09 Bezpečnostni softwarová asociace - Svaz softwarové ochrany v Ministerstvo kultury [2010] ECR I-13971 ("Bezpečnostni"); Joined Cases C-403/08 and C-429/08 Football Association Premier League Ltd v QC Leisure [2011] ECR I-9083 ("FAPL"); Joined Cases C-431/09 and C-432/09 Airfield NV v Belgische Vereniging van Auteurs, Compositien en Uitgevers CVBA (SABAM) [2011] ECR I-9363 ("Airfield"); Case C-283/10 Circul Globus Bucuresti (Circ \& Variete Globus Bucureşti) v Uniunea Compozitorilor şi Muzicologilor din România - Asociatia pentru Drepturi de Autor (UCMR - ADA) [2011] ECR I-12031 ("Circul"); Case C-135/10 Società Consortile Fonografici (SCF) v Del Corso [EU:C:2012:140] ("SCF"); Case C-162/10 Phonographic Performance (Ireland) Ltd $v$ Ireland [EU:C:2012:141] ("PPIL"); Case C-607/11 ITV Broadcasting Ltd v TVCatchup Ltd [EU:C:2013:147] (“ITV"); Case C-466/12 Svensson v Retriever Sverige $A B$ [EU:C:2014:76] ("Svensson"); Case C-348/13 BestWater International GmbH v Mebes [EU:C:2014:2315] ("BestWater"); Case C-351/12 OSA - Ochranný svaz autorský pro práva k dillưum hudebním o.s. v Léčebné láznĕ Mariánské Láznĕ a.s. [EU:C:2015:110] ("OSA"); Case C-151/15 Sociedade Portuguesa de Autores CRL v Ministério Público [EU:C:2015:468] ("SPA"); Case C-325/14 SBS Belgium NV v Belgische Vereniging van Auteurs, Componisten en Uitgevers (SABAM) [EU:C:2015:764] (“SBS"); Case C117/15 Reha Training Gesellschaft für Sport- und Unfallrehabilitation mbH v Gesellschaft für musikalische Aufführungs- und mechanische Vervielfältigungsrechte eV (GEMA) [EU:C:2016:379] ("Reha"); Case C-160/15 GS Media BV v Sanoma Media Netherlands BV [EU:C:2016:644] ("GS Media"); Case C-301/15 Soulier v Premier Ministre [EU:C:2016:878] ("Soulier"); Case C-138/16 Staatlich genehmigte Gesellschaft der Autoren, Komponisten und Musikverleger registrierte Genossenschaft mbH (AKM) v Zürs.net Betriebs GmbH [EU:C:2017:218] ("AKM"); Case C-527/15 Stichting Brein v Wullems [EU:C:2017:300] ("Filmspeler"); Case C-610/15 Stichting Brein v Ziggo BV [EU:C:2017:456] ("Pirate Bay"); Case C-265/16 VCAST Ltd v RTI SpA [EU:C:2017:913] (“VCAST”); Case C-161/17 Land Nordrhein-Westfalen v Renckhoff [EU:C:2018:634] ("Renckhoff"); Case C-263/18 Nederlands Uitgeversverbond v Tom Kabinet Internet BV [EU:C:2019:1111] (“Tom Kabinet”); Case C-753/18 Föreningen Svenska Tonsättares Internationella Musikbyrå u.p.a. (Stim) v Fleetmanager Sweden AB [EU:C:2020:268] ("Stim"); Case C-637/19 BY v CX [EU:C:2020:863] ("BY"); and Case C-392/19 VG Bild-Kunst v Stiftung Preußischer Kulturbesitz [EU:C:2021:181] (“VG Bild")).

107 Tuneln $v$ Warner (n13) [68]. Referring to the Information Society Directive, the Rental Right Directive, or Directive 93/83/EEC on certain aspects of copyright in satellite broadcasts and cable transmission.

108 See references in footnote 106. Arnold LJ offers a summary in Tuneln v Warner (n13) [70] (listing 15 principles).

${ }^{109}$ Together, PRS for Music: https://www.prsformusic.com/what-we-do/prs-and-mcps.
} 
Performance Ltd (PPL: licensing the use of recorded music) ${ }^{110}$ and VPL (sound recordings used in music videos). ${ }^{111}$

\section{c. Music Streaming: a Battle of Giants Drowning the Voices of Underrepresented Artists}

There is a real threat to leaving the under-represented groups of creatives behind in the current attempts to revive the creative industries. The issues of the DCMS inquiry on the Economics of Music Streaming are complex, and the number of stakeholders with their own narratives and agendas, almost blinding. If left unchecked, the Government risks drowning out the voices of the under-represented, such as women and gender minority creatives, by being blinded by the battling and opposing agendas of the giants in the industry.

To illustrate, the DCMS inquiry on the economics of music streaming heard from numerous stakeholders. Here, a clear tension between 'giants' was seen as representatives of the streaming platforms, ${ }^{112}$ traditional record labels (the Major Three), ${ }^{113}$ independent record labels ${ }^{114}$ and the CMOs were called to testify. ${ }^{115}$ The record labels testified to their commitment to represent the interests of their signed artists. Even if that statement is taken at face value, it does not change the evidence collected in 2019,116 demonstrating the severe underrepresentation of women in the repertoire of artists signed by the UK record labels. The third question posited by the DCMS Committee read:

"What has been the economic impact and long-term implications of streaming on the music industry, including for artists, record labels, record shops, etc?"117 (Emphasis added.)

Based on the evidence submitted to the DCMS Committee and currently made available in the public domain, ${ }^{118}$ it becomes clear that the "economic impact and long-term implications of streaming on ... artists" were not explored from the perspective of women, gender minority, independent or any other number of under-represented group of artists. Whereas it is true that on the whole almost all individual artists are not getting a fair deal from the current business models, this is no reason to neglect the under-represented groups in the UK music industries. At this junction, an opportunity has presented itself to 'build back better' through legislative intervention into the economics of music streaming, built on evidence. To avoid evidentiary bias, conscious or unconscious, a fair reform must include evidence, specifically provided by the under-represented groups of artists in the UK music industries.

\footnotetext{
${ }^{110}$ https://www.ppluk.com/.

111 VPL stands for Video Performance Licence, but VPL here, is the sister organisation (CMO) to PPL, which collects royalties on behalf of recording companies for music used in music videos: https://www.ppluk.com/music-licensing/music-video-licensing/.

112 Spotify, Apple Music, Amazon Music, Tencent Music, Deezer, YouTube Music, Pandora, SoundCloud, Tidal Music, Patreon, OnlyFans, TikTok. In The DCMS inquiry, representatives of Twitch, SoundCloud and YouTube (hearing on 10 February 20210); and Spotify, Amazon Music, Apple Music (hearing on 23 February 2021).

${ }^{113}$ Written and oral evidence heard (hearing on 19 January 2021).

114 Written and oral evidence heard (hearing on 4 February 2021).

${ }^{115}$ Written and oral evidence heard (hearing on 19 January 2021). Representatives of PPL and PRS for Music.

${ }^{116}$ Bain (n8).

117 See Section 2.2

118 See Section 2.3.
} 


\section{EVIDENTIARY GAP AS A SYSTEMIC PROBLEM IN THE UK MUSIC INDUSTRIES: FUTURE LEGISLATIVE INQUIRIES}

The argument presented in this paper is part of a larger debate, reaching beyond the confines of a single legislative inquiry. Already in sciences, strides have been made to avoid data bias and gaps in the collection of evidence, whether the position of women is at best disregarded, at worst, discounted. ${ }^{119}$ At the same time, IP law and regulation of the creative industries is consistently under review. At present the compound challenges of Covid-19 and Brexit are prompting a number of legislative inquiries. Collection of the evidence in these inquiries is not yet directed at collecting evidence from under-represented groups, who due to systemic barriers need their voices amplified by stakeholders, who already carry some power in the industry.

The DCMS Committee opened another legislative inquiry towards the end of 2020, which was to investigate the Future of UK Music Festivals. ${ }^{120}$ Whereas it is commendable that attempts are made to revive a sector, which was decimated in 2020, the statement made by DCMS Committee Chair Julian Knight MP makes it clear, that this will be a limited review, focusing on select issues only:

"The collapse of the vibrant music festival sector this year is a real cause for concern. The majority of festivals have been cancelled with the money they generate down by $90 \%$ and real risks surrounding their future viability.

We have so many legendary festivals that have given the UK a worldwide reputation it would be devastating if they were unable to come back with a bang, or if smaller festivals that underpin the talent pipeline disappear entirely. We want to hear from festival staff as they face huge pressures, fans who've missed out, as well as musicians on the contribution that festivals make to our culture and economy.

It's crucial that support to enable music festivals to go ahead in 2021 and beyond is put in place. We'll be assessing what's been done so far and what more needs to be done to safeguard the future of festivals." 121

The Terms of Evidence stipulate the following scope of inquiry:

"1. What is the economic and cultural contribution of the UK's festival industry?

2. What has been the impact of cancellations on local economies and those who derive income from festivals during 2020 ?

3. What are the risks to festivals taking place in 2021 and beyond, and how can these be mitigated?

4. What measures are needed for audiences to attend festivals without social distancing, and how realistic are they?

5. What has been the impact of the temporary VAT cut and Culture Recovery Fund on festivals and their supply chains, and what else can the Government do to secure their futures?

\footnotetext{
${ }^{119}$ For a broader discussion: Criado Perez (n1).

${ }^{120}$ For a general overview: https://committees.parliament.uk/work/779/the-future-of-uk-music-festivals/.

121 Statement on the DCMS inquiry website: https://committees.parliament.uk/committee/378/digital-culture-media-and-sportcommittee/news/123465/dcms-committee-to-examine-the-future-of-uk-music-festivals/.
} 
6. How has the structure of the UK festivals market evolved over recent years, and what has this meant for consumers, artists and the wider industry? What further changes might be anticipated?

7. How can festivals be supported to reduce their environmental impact and tackle the dangers of illegal drug use?"122

There is a significant area of concern, which the DCMS Committee should have included in its scope of inquiry, yet unfortunately that has not been done. It has been reported in the industry for a number of years, that women remain severely under-represented and excluded from festival line-ups or as headliners. ${ }^{123}$ The promise of a gender 50:50 split in UK music festivals by 2022, to which 45 festivals signed up to in 2019 (including the BBC Proms, Cheltenham Jazz Festival and Liverpool Sound City) is unlikely to come true, without a purposeful intervention. The gender statistics are still far from ideal:

"[a]ccording to Female Pressure Analysis of 166 Global Electronic Festivals (2012-2019) show that only $17.3 \%$ of acts are female, $6.9 \%$ are mixed acts and a staggering majority of $74 \%$ are male. In 2018, Wireless Festival only booked 5 female acts. We know that there are thousands of female artists, we know that there are fantastic female musicians in every genre, so it is not down to lack of talent available, just gender inequality and a male-dominated industry not making the necessary steps for parity." ${ }^{124}$

This was a problem pre-dating the Covid-19 crisis, and even with signals of festivals reopening in 2021, the opportunity to 'build back better' has not been taken up by the major festivals, booking agents and other industry players. ${ }^{125}$ In response to this systemic exclusion and underrepresentation of women in the UK music industries, a researcher and campaigner Vick Bain, with decades of experience in the music industries, started a practical solution and response to the many actors claiming that there are simply not enough women to book and include in festival line-ups. Since early 2020, it is now possible to find thousands of women and gender minority musicians, active across the UK, and across all genres. The F-List for Music records over 5,100 entries of women and gender minority artists, ${ }^{126}$ available for booking or other professional opportunities.

Despite this background and context, the DCMS Committee did not take the opportunity to address gender discrimination in UK festivals. This is a missed opportunity, which means that aims such as gender equality and representation of under-represented artists in the UK music industries will depend on the commitment and sporadic funding for non-profit

\footnotetext{
122 Listed online, inviting stakeholders to submit evidence: https://committees.parliament.uk/call-for-evidence/309/the-future-ofuk-music-festivals/.

${ }^{123}$ In response to the severe under-representation of women on the festival circuits, the Primavera Sound Festival (2019) was the first festival to aim for, and finally to have a 50-50 split line-up between male and female performers: https://www.thestrandmagazine.com/single-post/2019/06/13/the-new-normal-at-primavera-sound.

${ }^{124}$ Stinton (n20) reporting in 2021.

${ }^{125}$ Reports in April 2021 confirm that the gender imbalance has not been corrected: Helen Packer, 'The Festivals are back, but where are the women?' (Internation, 20 April 2021): http://internation.maijcityjournalism.uk/arts-culture/festivals-are-back-but-where-arethe-women/. To start with, it was reported that "[a] study by Female:Pressure found that, between 2017-2019, only 20\% of acts booked for the electronic music festivals it surveyed were female" which has not improved in 2021.

126 Open-access directory: https://thef-listmusic.uk/. Listings are welcome from all women. Women is an all-inclusive term (including trans-women, gender minorities or non-binary artists).
} 
organisations, such as The F-List for Music, ${ }^{127}$ KeyChange, ${ }^{128}$ or Women in CTRL. ${ }^{129}$ The F-List for Music $\mathrm{CIC}$ embeds its registry in the broader vision of ensuring that women are able to start, and sustain professional careers in the UK music industries. In order to do that, The F-List investigates the systemic barriers that exist and collaborates with sister organisations ${ }^{130}$ in raising awareness around the issues and offering training and professional opportunities to overcome the structural barriers. KeyChange participates not only in the pursuit of gender equality in the music industries in the UK, but also seeks this goal on a European level, ${ }^{131}$ with projects such as Musica Femina, ${ }^{132}$ Mewem Europa, ${ }^{133}$ Future Female Sounds, ${ }^{134}$ Musique est une Femme, ${ }^{135}$ and ESCA Working Group on Gender and Equality. ${ }^{136}$ Women in CTRL is another organisation, seeking to establish spaces, safe for womxn in the music industries, where diverse voices are heard, and their lived experiences shared. It is important these stories are told, as "stories are reflection of the current norm for womxn in the industry, and by listening we become aware of the problems that exist and where you can help."137

The UK Government, and the DCMS Committee are running several legislative inquiries into the creative industries. Their current approach to the rules regulating this area is 'genderblind' where 'an artist' or 'a creative' is 'a talented individual' without distinctive personal characteristics. Here, gender, race, age, disability, class are not considered determinative in evidence collection or future policy design. Rules regulating the industry, be it business, contract or IP rules, are seen as gender neutral. With the UK leaving the EU, and the transition period ending on 31 December 2020, the UK Government needs to determine the direction of its future policy regarding the music industries, and more broadly the creative industries. With opportunities and challenges abound, it is suggested here, that the Government takes a more directed approach towards 'building back better' and ensuring a fairer, and more inclusive creative industries.

\section{CONCLUSION}

It is argued here that a gender-neutral stance of the current DCMS legislative inquiries into the UK music industries is ignoring the existing data of structural barriers that women and gender minority artists in the music industries face when seeking professional opportunities to start or sustain their music careers. As the discussion around music streaming demonstrates, the solutions that stakeholders are currently recommending as the cure to the existing inequalities, are still not taking into consideration the specific circumstances of the under-represented voices in the industries, and are based on evidence, which is not gender segregated.

The DCMS Committee was dedicated to find solutions to the streaming problem by asking the stakeholders in the oral hearings for their recommendations. The industry actors

\footnotetext{
127 https://thef-listmusic.uk/what-we-do/what-do-we-do/.

${ }^{128}$ https://www.keychange.eu/ ("a movement that counts the discounted. We take action to empower talented underrepresented genders with training, mentoring, and network support plus conferences and showcasing opportunities at partner festivals").

129 https://linktr.ee/Womaninctrl.

${ }^{130}$ Listing over fifty sister organisations: https://thef-listmusic.uk/who-we-are/sister-organisations/.

131 https://www.keychange.eu/about-us/news-feed-articles/5-european-projects-working-towards-a-gender-balanced-musicindustry

132 https://www.musicafemina.at/.

$133 \mathrm{https}$ ///lelaba.eu/projet/mewem-europa/.

134 https://www. futurefemalesounds.org/.

135 https://fundacjatak.pl/en/musique-est-une-femme/.

136 https://composeralliance.org/ecsa-gender-working-group/.

${ }^{137}$ Founder Nadia Khan: https://thefac.org/news-directory/music-industry-its-time-to-listen-to-womxn.
} 
continued the discussion even in industry organised panels, ${ }^{138}$ and recommended a range of changes to the system, including (1) changes to how much we charge for streaming, focusing on 'average rate per user' (ARPU), which is to replace the rate per stream; (2) changes to the streaming services business models, which would shift towards a user-centric model, which would channel the payments of users towards the artists they listen, not in a 'general pot of profits;' (3) a better distribution of profit share between songwriters, record labels, artists and streaming services; ${ }^{139}$ (4) better industry regulator; (5) raising awareness around ways in which consumers can support their favourite artists; ${ }^{140}$ (6) increasing transparency in data and records keeping, including a better communication between song registration codes and recording registration codes, which cause delays in transfer of profits from record labels to individual artists; (7) standardisation of data, ${ }^{141}$ to avoid unattributable income (where it is unclear which artist is to be paid for a particular song); (8) a call for all creatives and artists to join their representative organisations.

In order for the UK Government and the DCMS Committee to draw a list of recommendations for reform, which will create a more inclusive and fair music industries, the evidence collected must be gender segregated. A gender-neutral stance creates the risk of perpetuating gender bias, which has already been shown to exist in industry reports since 2019 onwards. ${ }^{142}$ IPSJ and feminist theory suggest that legal rules and practices, which are apparently gender neutral, tend to favour the group, which has traditionally seen their voices heard and represented. It is a mistake, or a confusion, to assume that the way in which male artists are affected by rules governing commercial exploitation of their musical works, is the same as the effect these rules have on women or gender minority artists. As per relational legal feminism, all human experience is to be valued, and the law should shift its focus from valuing the outputs of humans, as opposed to their experience. Relying on IPSJ theory, IP rules could, when informed through a gender-segregated evidence base, give access, empower and include the individual artists, currently under-represented in the UK music industries. Ownership of the obligation to amplify the voices of the under-represented in the music industries rests with, it is argued here, the UK Government. This is a policy choice of inclusion, which this article argues, would benefit everyone, on the long run.

\footnotetext{
138 Industry Panel organised by the Ivors Academy, featuring Tom Gray (musician and \#BrokenRecord), Emma Pollock (creator and Chemical Records (=indie label from Scotland), Stuart Braithwaite (creator and Mogwai Young Team (= indie label from Scotland) and Ray Black (music talent manager) (online, 8 April 2021). Event note: https://ivorsacademy.com/event/streaming-yourroyalties/.

${ }^{139}$ For example, the current split of: 30\% (streaming services) + $55 \%$ (record labels, which includes artists) + $15 \%$ (song publishers, song writers) would be replaced with: $25 \%$ (songwriters) $+25 \%$ (record labels) $+25 \%$ (artists) $+25 \%$ (streaming services). This recommendation made by the Industry Panel referenced at (n136).

140 The Industry Panel (n136) referred to services such as Band Camp: https://bandcamp.com/ (where artists gain profit directly from the sales made by their fans and supporters.

141 Currently, songs must be registered with PRS for Music (https://www.prsformusic.com/works/registering-works) and recordings must be registered with PPL, and the attached code with the PPL registration is linked to the ISRC number, which is based on an International Standard Recording Code (ISRC) system, which serves the identification of recorded music and music videos: https://isrc.ifpi.org/en/.

${ }^{142}$ See references at (n8) and at (n15).
} 


\section{Post Scriptum:2021 DCMS July Report on Economics of Music Streaming}

Since the acceptance of this article for publication, the DCMS Committee released its full report on the Economics of Music Streaming inquiry on 9 July 2021. ${ }^{143}$ As the full one hundred and twenty-two pages of the report might not be fully accessible to all readers, the DCMS Committee also released an interactive, brief version of the findings. ${ }^{144}$ Here, the several recommendations from the full report are summarised in five key solutions to 'fix the problem':

1. Artists should be given "equitable remuneration now."

$\Rightarrow$ Action: "The Government should enact legislation so performers can enjoy the right to equitable remuneration for streaming income."

2. To increase the value of the song, the committee recommends "revenue parity for songwriters and composers."

$\Rightarrow$ Action: "The Government should work with creators and the independent publishing sector to explore ways in which new and upcoming songwriters and composers can be supported to have sustainable careers and independent music publishers remain commercially viable."

3. There must be a study into the "market power in the music industry."

$\Rightarrow$ Action: "We recommend that the Government refer a case to the Competition and Markets Authority (CMA), to undertake a full market study into the economic impact of the majors' dominance. The Government must also provide the CMA with the resources and staffing to undertake this case."

4. There must be fairness and transparency of algorithms and playlisting.

$\Rightarrow$ Action: "Where curators are paid or receive benefits in kind for playlisting, we recommend that they are subject to a code of practice developed by the Advertising Standards Authority (similar to social media influencers) to ensure that the decisions they make are transparent and ethical."

5. The current framework on online intermediaries and safe harbour is a cause of concern and needs reform.

$\Rightarrow$ Action: "As a priority, the Government should introduce robust and legally enforceable obligations to normalise licensing arrangements for User Generated Content hosting services, to address the market distortions and the music streaming 'value gap'."

These recommendations are welcome and will serve as useful guidance to the discussions in the House when the Music Streaming Bill will be heard. The first reading is set for 3 December 2021 (i.e. Copyright (Rights and Remuneration of Musicians etc) Bill). ${ }^{145}$ The recommendations

\footnotetext{
${ }^{143}$ DCMS, 'Economics of Music Streaming' (2021) Second Report of Session 2020-21 (report, together with formal minutes relating to the report) (9 July 2021). The full report can be accessed and downloaded here: https://committees.parliament.uk/publications/6739/documents/72525/default/.

$144 \quad$ Available: $\quad$ https://houseofcommons.shorthandstories.com/music-streaming-must-modernise-DCMSreport/index.html?utm_source=committees.parliament.uk\&utm_medium=referrals\&utm_campaign=economics-musicstreaming\&utm_content=organic.

${ }^{145}$ Confirmed by Kevin Brennan MP (16 June 2021): https://twitter.com/KevinBrennanMP/status/1405170680300179461.
} 
and findings of the report however do not take away the urgency of the call put forward in this article. The lengthy report, although welcome, does not mention gender, women, or gender minority artists at all. The category of the creatives ('artists') remains gender-neutral. Recommendations 1,2 and 4 will benefit from gender specific evidence, which will inform policy and the future direction of relevant regulation. As reported above, women and gender minority artists are not equally represented in the industries. Equally, algorithms and Al bias is a great problem, ${ }^{146}$ which if left unaddressed, could propel the current injustices even further.

146 See references (n10). 